\title{
Urban sprawl: mobility potentials in suburban areas of Tallinn
}

\author{
R. Mäe, D. Antov \& I. Antso \\ Faculty of Civil Engineering, Tallinn University of Technology, Estonia
}

\begin{abstract}
The travel habits of commuters have a huge impact on sustainable development in general, as well as for certain regions or cities. This is also a case for the city of Tallinn, capital of Estonia, where important changes in mobility have been taking place over the last 20 years. These changes could mainly be described by the rapid motorization, growth of motorized traffic and decline in the usage of public transport, as well as by the sprawl of the city, where former agricultural areas are turned into residential ones. Thus, it is very important: i) to analyze present trends of mobility, not only in the city but in the bigger area of mobility around the city; ii) to develop modern and user friendly methods for the mobility outcome, especially based on public databases, which include data about land use characteristics, residencies and job location and mobility characteristics, including travel mode, time and length.

The main goal of this research is to: a) investigate the main mobility characteristics between Tallinn and its suburban areas - commuting area; b) determine the commuting areas - represented in time and space units of the regular mobility near the city of Tallinn; c) find the main causes, which are affecting certain transport mode usages and how can we influence these choices; d) analyze the potentials of different mobility model usage for mobility forecasting in the commuting area of the city of Tallinn.

Keywords: suburbanisation, urban sprawl, commuting, traffic volume, mobility, territorial planning, public databases.
\end{abstract}

\section{Introduction}

The word sprawl has entered our daily language, and the descriptions and analyses of its characteristics have filled articles, papers, and books in a torrent 
during the last decade. The problems of a highly inefficient built environment with much social isolation and segregation have been well documented. It is also clear that this is how the overwhelming majority of families wish to live - as long as they can reasonably bear the costs of acquiring a parcel of land with a house and are willing to accept long trips each day by every family member. Undoubtedly, the private automobile (or two or three per family) is the active ingredient in the creation of this situation [1].

Urban sprawl is the growth of residential areas beyond the current spatial limits of compact urban development. Such sprawl necessitates that urban services and utilities be provided to areas where the population density remains low, thereby resulting in excessive costs is being borne by city taxpayers or on other customers of the utilities that are required to serve these areas. Burgeoning urban sprawl may even require the city or utility to purchase additional equipment [2].

The use of this land beyond the urban area for housing or economic activities is made possible because of a lack of land use controls. If the land were zoned for non-residential or non-commercial activities (e.g., agriculture or open space), then there would be no sprawl. In effect, although transportation is usually held responsible for urban sprawl, transportation facilities (specifically highways) only allow movement to or from areas beyond the periphery or our cities. Transportation in and of itself does not create sprawl, but transportation without land use control may facilitate it [2].

Urban sprawl is a relatively new process for Estonia that has not revealed itself to the full extent yet because of the economic crisis. Traffic volumes on the city-border of Tallinn have decreased since 2008, as Figure 2 shows. It is clear that urban sprawl is a process underway and it has already developed to some level but it is most likely to continue to develop faster after the economy recovers. The numerous detailed plans for the territory of parishes near Tallinn suggest that the mobility demand will increase again.

To determine the mobility demand the following databases have been analysed in our work: the Population Register, the database of Estonian Tax and Customs Board and Statistic Estonia. In this work we are also analysing some main demographic processes, changes in age structure over time and its impact on traffic and mobility.

\section{Data and methods}

In our work we used the data from the following sources: traffic counts executed by Tallinn University of Technology, Tax and Customs Board database, Estonian Road Administration (Road Register), Statistics Estonia, City of Tallinn, Department of Education, Elektriraudtee AS (commuter train company), and Harju Public Transport Centre.

To determine the commuting areas the databases of Road Register and Estonian Tax and Customs Board have been analysed, which is including the data about employers and employees who are registered in Harju County - the largest as to the population (542975 people) and the second largest as to the total 
area $\left(4333.13 \mathrm{~km}^{2}\right)$. The centre of the county is Tallinn, which is also the capital of Estonia. The data originate from 2011 and are impersonal, which means that they cannot be related to a specific person or company. The data are marked with the EHAK location code (Estonian Administrative and Settlement Classification) and the smallest settlement unit is the village. In the present paper, data have been aggregated to the level of parishes, that is, the data of villages that belong to a certain parish have been added together. Furthermore, it was calculated how many work places there are in the settlement unit and how many of these have been manned by local inhabitants and where the rest of the employees come from.

The database of the Tax and Customs Board and the number of students most definitely does not correspond to reality as:

- The accounting of large companies is central, which means that the branches of a company may be located all over Estonia, but employees are registered in the head office (Tax and Customs Board);

- Also, people do not necessarily live at the same address where they are registered to; for example, for the purposes of receiving a certain grant or for political purposes [3];

- Similarly, the permanent address registration of children is also manipulated with, in order to register the child in a specifically desired school [3].

In addition to the employees, the number of students who go to school, but live outside Tallinn, has also been analysed. Officially there are 1018 students studying in schools of Tallinn, but living outside Tallinn (Tallinn Education Department 2007), which is $1 \%$ of all commuters.

To investigate the main mobility characteristics between Tallinn and its suburban areas the annual traffic survey (conducted by Tallinn University of Technology) and the surveys of Institute of Geography (conducted by University of Tartu) have been analysed.

\section{Results}

Table 1 presents the data received from the Tax and Customs Board about the place of residence and work of people in Harju County, which have been added up by parishes. The first column states the name of the local municipality, the second column shows the number of work places in the municipality, the third shows the number of employees in the municipality, the fourth shows how many local people work in their place of residence, the fifth shows the percentage of local people working in the municipality, the sixth column shows how many people in this municipality work in Tallinn, the seventh column indicates the percentage of people in this municipality who are working in Tallinn, the eighth column shows the distance between Tallinn (measured from Viru Square) and its neighbour municipality (measured from the centre point of municipality).

Data in Table 1 are reflected indirectly in the annual survey conducted by Tallinn University of Technology (Figure 2), which shows that since the restoration of independence (1991) until today (2011) the traffic volumes on the 
Table 1: $\quad$ The database of Estonian tax and customs board.

\begin{tabular}{|c|c|c|c|c|c|c|c|}
\hline Local municipality & $\begin{array}{c}\text { Number of } \\
\text { worksplaces }\end{array}$ & $\begin{array}{l}\text { Number of } \\
\text { Employees }\end{array}$ & $\begin{array}{c}\text { Of which } \\
\text { local } \\
\text { residents }\end{array}$ & $\begin{array}{c}\text { Local } \\
\text { people } \\
\text { percentage }\end{array}$ & $\begin{array}{l}\text { Working } \\
\text { in Tallinn }\end{array}$ & $\begin{array}{l}\text { Working in } \\
\text { Tallinn [\%] }\end{array}$ & $\begin{array}{c}\text { Distance } \\
\text { from } \\
\text { Tallinn } \\
{[\mathrm{km}]}\end{array}$ \\
\hline 1 & 2 & 3 & 4 & 5 & 6 & 7 & 8 \\
\hline City of Tallinn & 237461 & 157760 & 134188 & $56,5 \%$ & 134188 & $85,1 \%$ & - \\
\hline Viimsi parish & 4899 & 6847 & 1189 & $24,3 \%$ & 4754 & $69,4 \%$ & 11 \\
\hline Harku parish & 2981 & 5238 & 814 & $27,3 \%$ & 3466 & $66,2 \%$ & 24 \\
\hline Kiili parish & 749 & 1881 & 307 & $41,0 \%$ & 1223 & $65,0 \%$ & 28 \\
\hline Rae parish & 10464 & 5506 & 1292 & $12,3 \%$ & 3520 & $63,9 \%$ & 18 \\
\hline Saue parish & 3238 & 3842 & 578 & $17,9 \%$ & 2417 & $62,9 \%$ & 24 \\
\hline Jõelähtme parish & 2176 & 2573 & 598 & $27,5 \%$ & 1504 & $58,5 \%$ & 22 \\
\hline Saku parish & 4534 & 3743 & 903 & $19,9 \%$ & 2180 & $58,2 \%$ & 25 \\
\hline Maardu town & 5006 & 6640 & 1655 & $33,1 \%$ & 3855 & $58,1 \%$ & 20 \\
\hline Saue town & 2537 & 2532 & 565 & $22,3 \%$ & 1445 & $57,1 \%$ & 24 \\
\hline Aegviidu parish & 149 & 316 & 75 & $50,3 \%$ & 175 & $55,4 \%$ & 64 \\
\hline Kernu parish & 242 & 760 & 155 & $64,0 \%$ & 413 & $54,3 \%$ & 51 \\
\hline Raasiku parish & 1343 & 1875 & 509 & $37,9 \%$ & 1001 & $53,4 \%$ & 26 \\
\hline Keila parish & 635 & 1907 & 202 & $31,8 \%$ & 972 & $51,0 \%$ & 28 \\
\hline Kuusalu parish & 1383 & 2642 & 839 & $60,7 \%$ & 1310 & $49,6 \%$ & 55 \\
\hline Keila town & 4534 & 4301 & 1489 & $32,8 \%$ & 2013 & $46,8 \%$ & 28 \\
\hline Kose parish & 1167 & 2341 & 835 & $71,6 \%$ & 1054 & $45,0 \%$ & 39 \\
\hline Kõue parish & 334 & 666 & 193 & $57,8 \%$ & 290 & $43,5 \%$ & 65 \\
\hline Paldiski town & 898 & 1563 & 560 & $62,4 \%$ & 662 & $42,4 \%$ & 48 \\
\hline Vasalemma parish & 990 & 944 & 169 & $17,1 \%$ & 382 & $40,5 \%$ & 46 \\
\hline Anija parish & 1215 & 2378 & 942 & $77,5 \%$ & 922 & $38,8 \%$ & 57 \\
\hline Nissi parish & 469 & 1157 & 301 & $64,2 \%$ & 448 & $38,7 \%$ & 57 \\
\hline Padise parish & 438 & 763 & 229 & $52,3 \%$ & 281 & $36,8 \%$ & 62 \\
\hline \begin{tabular}{|l|} 
Loksa town \\
\end{tabular} & 593 & 1028 & 437 & $73,7 \%$ & 318 & $30,9 \%$ & 69 \\
\hline sum total: & 288435 & 219203 & 149024 & $51,7 \%$ & 168793 & $77,0 \%$ & \\
\hline
\end{tabular}

city-border have increased about 1.7 times. This can be explained by changes in land use near Tallinn - people have moved out of Tallinn, but have remained involved with Tallinn (through jobs, schools, shopping, etc.) which in turn leads to commuting.

Figure 1 shows that, as the traffic growth rate has increased after the restoration of independence, the number of passenger cars has as well. The growth has been rapid since 1990 but for the last 6 years (2006 to 2011) it has remained essentially at the same level. We can see a big fall in 2001, which is related to reviewing the traffic register and the removal of vehicles that do not actually circulate the streets [4].

Figure 2 shows the changes in traffic volumes at the cordon of city-borders compared to the traffic in 1973. Evening peak-hour traffic is counted from $3 \mathrm{pm}$ to $6 \mathrm{pm}$ (15:00 - 18:00). Traffic volumes peaked in 2008 [5].

In 1990 Harju county had a population of 607158 and by 2010 the number was 526505 , which means that over the course of 20 years the population of Harju County has declined by 80653 people [4] while traffic volume has dramatically increased. 


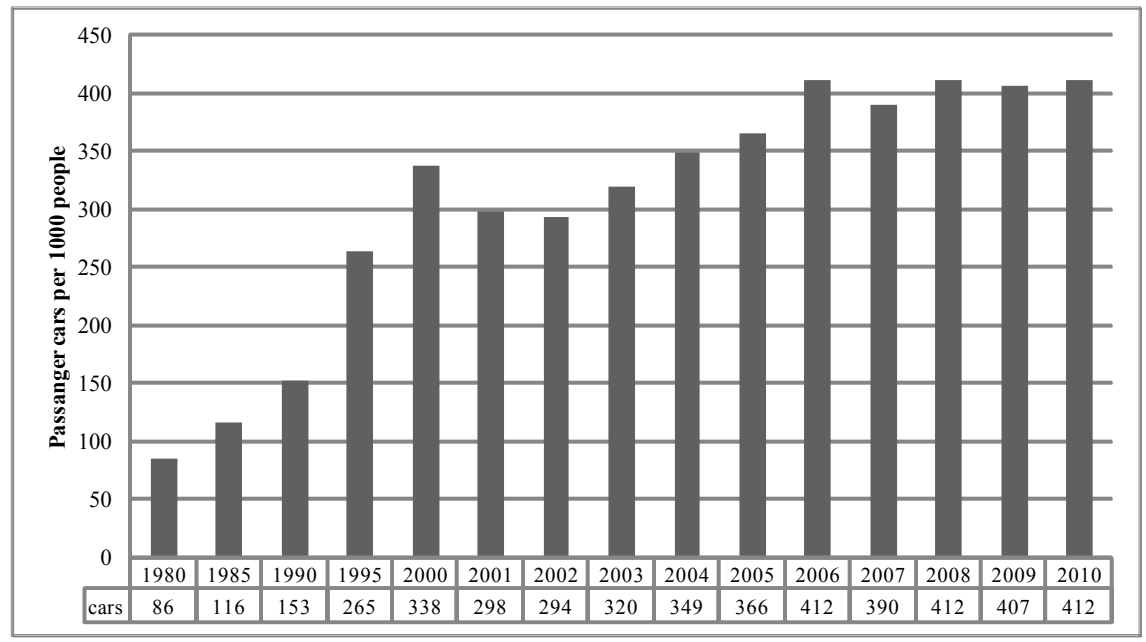

Figure 1: $\quad$ Cars per 1000 people [4].

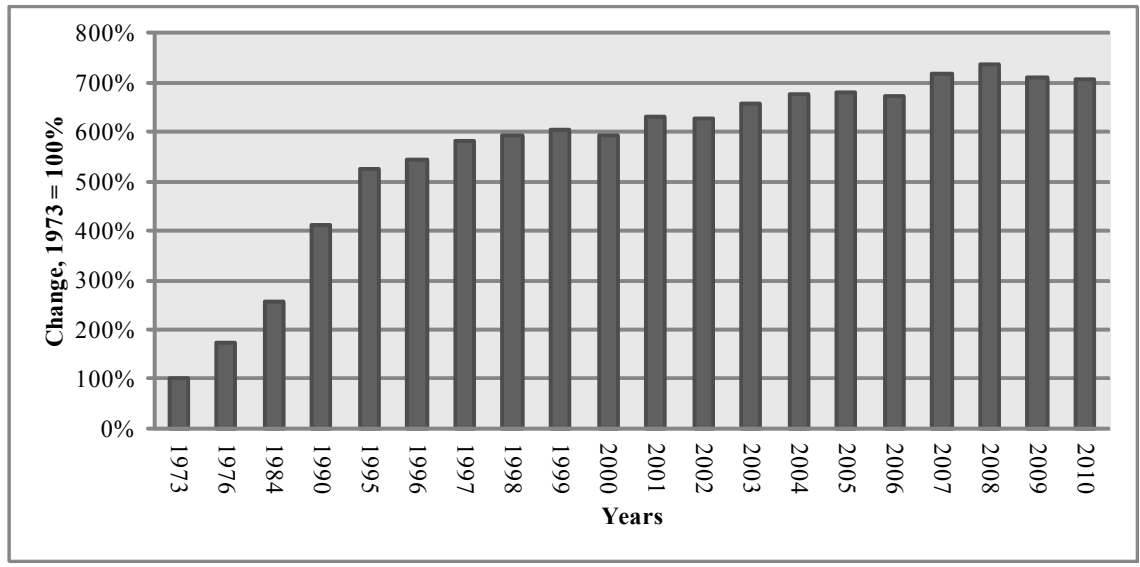

Figure 2: Change of traffic volumes in evening peak hour on Tallinn cityborder [5].

\subsection{Population prognosis}

The rapid development of Estonian society during the recent years requires the recalculation of the prognosis. The following scenarios have been outlined.

Variant 1 was based on traditional assumption that the initial data used in the model will remain unchanged for the whole observed period and migration will not be considered.

Variant 4 (basic) was based on assumption that the initial data used in the model (indicators of fertility and mortality) would change: life expectancy at 
birth and total fertility rate was expected to grow. In variant 4 the calculations were made for regions (NUTS3 level).

The variant 3 was calculated only as extremes for finding the variation borders.

One can see from the calculations that the population at the end of the period would be less than one million only in variant 1 (invariable fertility and mortality). The age pyramid would decrease significantly especially in workingage groups [6].

The forecast of the population pyramid shows that population are reduced but a decline in the population alone does not necessarily solve the traffic problems caused by urban sprawl. This is underscored by the fact in 20 years Harju County's population declined by $13 \%$, at the same time the traffic volumes on the city-border increased by $300 \%$ (Figure 2). However, the mobility demand may be affected by changes in population age composition (i.e. as we see in Figure 5, there will be a significant decline of the population at working age) since most of the commuters are working-age people. This means that a decline in the working age population will decrease mobility demand on Tallinn cityborder.

\subsection{Main mobility characteristics between Tallinn and its suburban areas}

Suburbanization has had major effect on the development of surrounding municipalities of Tallinn. Urban sprawl has most intensively influenced Viimsi municipality, which has been one of the fastest growing municipalities in Estonia over last two decades. Due to its closeness to Tallinn and good quality of life Viimsi municipality has become an attractive place for living, especially amongst young and successful families. This phenomenon has been related to the extreme lack of contemporary urban housing and a high quality living environment in the city. Therefore people who prefer the urban environment move to areas very close to Tallinn [7]. The number of residents has been increasing continuously. In 2001 Viimsi municipality only had 5758 inhabitants. In ten years the population has more than tripled (17 093 inhabitants in 2011) with $90 \%$ of the population growth caused by migration and only $10 \%$ by natural increase (according to the sources of Viimsi municipality).

Approximately $69 \%$ of working inhabitants of Viimsi municipality (Table 1) have a workplace in Tallinn and only $17 \%$ are working in their own municipality. The high share of daily commuters shows the close relation and dependence of Tallinn. Local inhabitants mostly drive to Tallinn. Approximately $88.7 \%$ of all trips are made by car, only $12.3 \%$ by public transportation. Due to the increase in population and commuters the number of cars heading to Tallinn during the morning peak hour ( $8 \mathrm{am}$ to $9 \mathrm{am}$ ) has increased by $27 \%$ (between 2001 and 2011) reaching 1800 . Most of the traffic (61.7\%) uses the same one of the four roads that connects Viimsi municipality with Tallinn.

Increasing commuter rates have led to an increase in traffic volume and have caused a decrease in average speed (Figure 3). Average speed of traffic was on a continuous decline until 2007 when the traffic situation was the worst since the beginning of suburbanization. In 2007 it took twice as long to drive the same 
distance as it did in 2003. Although the situation has improved since 2007 because of a decrease in traffic caused by the economic crises the traffic rate is increasing again and the existing situation is almost the same as in 2007. Thus urban sprawl has had a major effect on the traffic situation and therefore to people's daily lives.

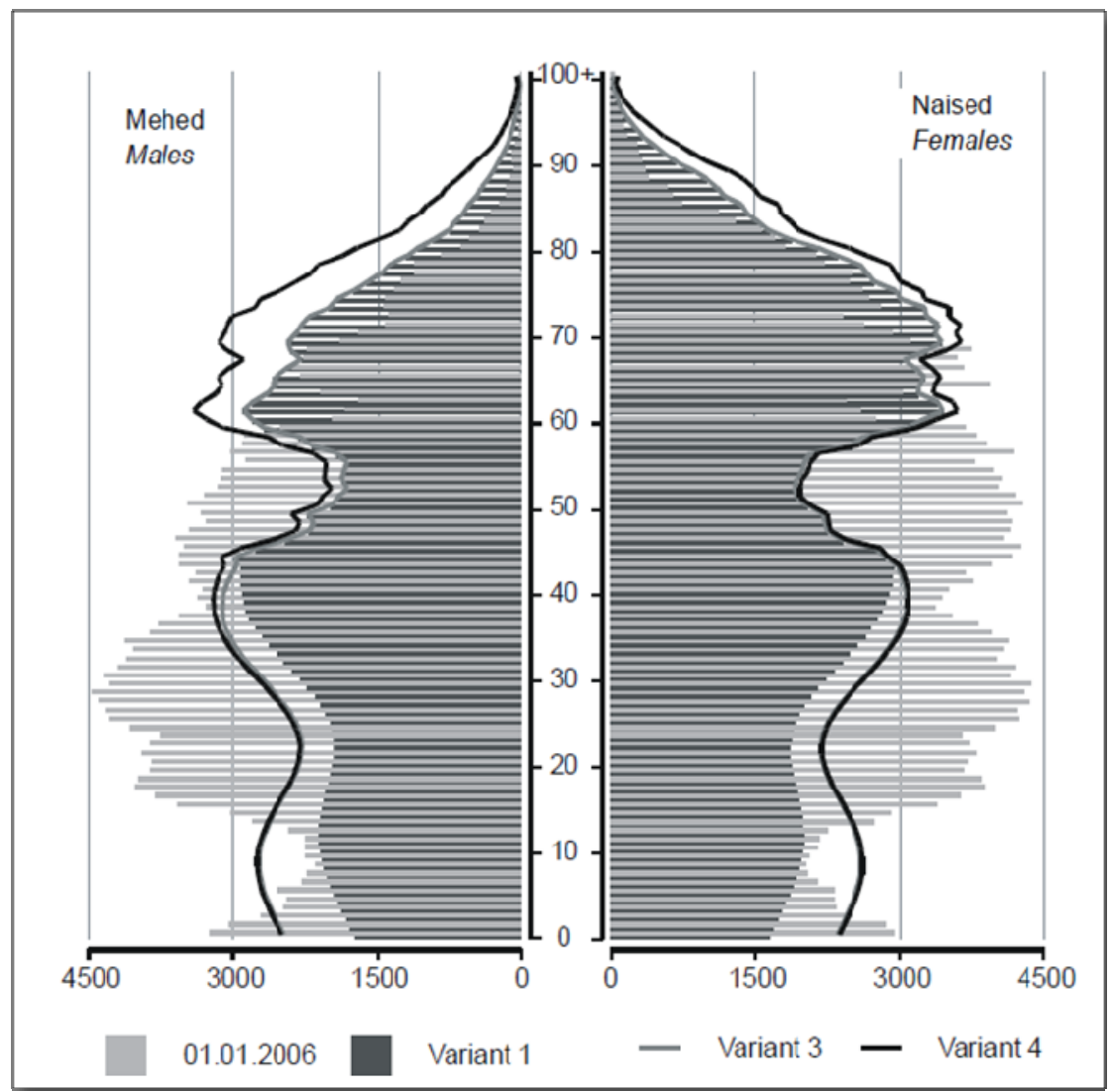

Figure 3: $\quad$ Population pyramid of Northern Estonia, 2006 and 2050 [6].

\subsection{Determination of the commuting areas}

To determine the commuting areas - represented in time and space units of the regular mobility around the city of Tallinn - the traffic counts (Table 2) [8] and database of the Tax and Customs Board have been analysed (Table 1: columns 7 and 8).

As we see in Figure 4 there is a correlation between the distance from Tallinn and the ratio of employees who are living in Tallinn's suburb but working in Tallinn. Table 2 shows that traffic volumes decline after 30 kilometres. In other words: the closer to Tallinn the higher the percent of residents working in 
Tallinn. According to the Road Register (Table 2) and the database of Tax and Customs Board it can be argued that the everyday commuting zone of Tallinn is approximately 30 kilometres. This means that the numbers of traffic volumes and the residents working in Tallinn start to drop after 30 kilometres.

Table 2: $\quad$ Annual average daily traffic (2010) [8].

\begin{tabular}{|c|c|c|c|c|}
\hline Road No & Road Name & $\begin{array}{c}\text { Section } \\
\text { start }(\mathrm{km})\end{array}$ & $\begin{array}{c}\text { Section } \\
\text { end (km) }\end{array}$ & AADT \\
\hline \hline 4 & Tallinn - Pärnu - Ikla & 13 & 14 & 30317 \\
\hline 4 & Tallinn - Pärnu - Ikla & 14 & 18 & 18077 \\
\hline 4 & Tallinn - Pärnu - Ikla & 18 & 27 & 12233 \\
\hline 4 & Tallinn - Pärnu - Ikla & 27 & 39 & 6486 \\
\hline 1 & Tallinn - Narva & 10 & 11 & 25560 \\
\hline 1 & Tallinn - Narva & 11 & 16 & 20835 \\
\hline 1 & Tallinn - Narva & 16 & 26 & 14320 \\
\hline 1 & Tallinn - Narva & 26 & 40 & 8915 \\
\hline 2 & Tallinn - Tartu - Võru - Luhamaa & 6 & 9 & 18150 \\
\hline 2 & Tallinn - Tartu - Võru - Luhamaa & 9 & 12 & 15725 \\
\hline 2 & Tallinn - Tartu - Võru - Luhamaa & 12 & 21 & 10799 \\
\hline 2 & Tallinn - Tartu - Võru - Luhamaa & 21 & 33 & 8835 \\
\hline
\end{tabular}

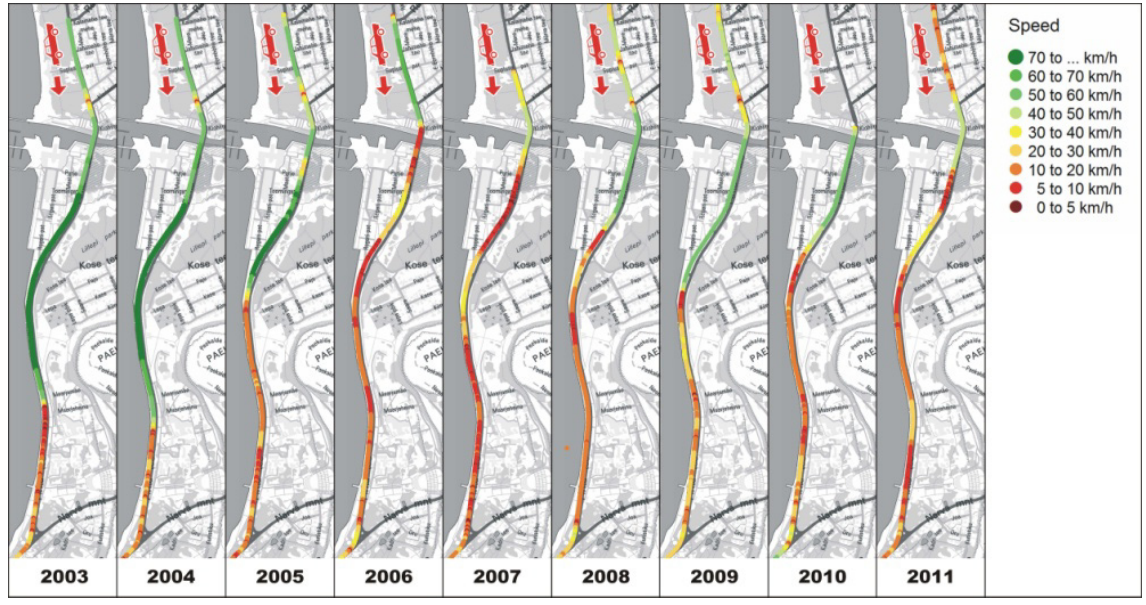

Figure 4: $\quad$ Average traffic speed between Viimsi and Tallinn (2003-2011). 


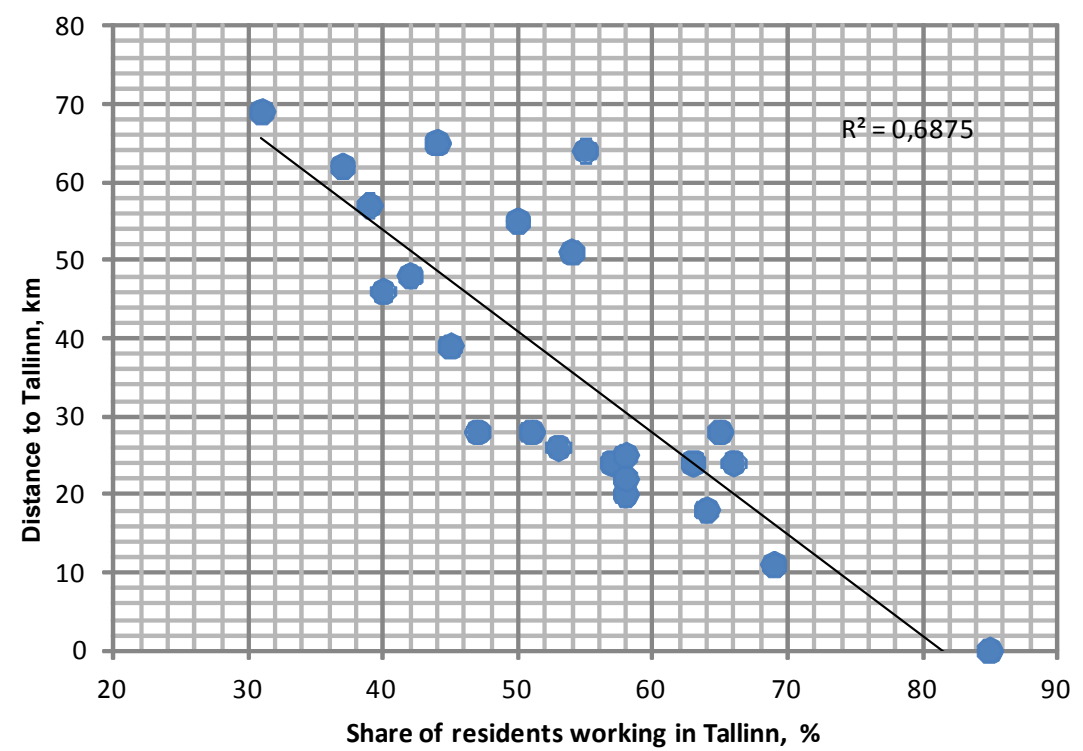

Figure 5: Correlation between distance from Tallinn and the ratio of employees who are living Tallinn's neighbourhood and are working in Tallinn.

\subsection{Different mobility models usage in suburban areas}

Suburban people have three realistic alternatives for commuting: personal car, bus, train and combination of these three.

According to the data of Elektriraudtee AS (commuter Train Company) 2173 people commute daily by commuter train, but there is no information available about the number of daily bus travellers. Looking at the schedules (according to the sources of the Journey Planner) of the regional buses that serve in the immediate vicinity of Tallinn, we can say that the number of bus travellers is insignificant. The number of buses serving the neighbouring areas of Tallinn is too low to dominate in the proportions of mobility models.

The situation has not changed compared to 2006 when the Institute of Geography (University of Tartu) made a survey on a similar topic. For an example, the analysis of choices for commuting modes indicated that the public transport network in the capital city region of Estonia is not functioning properly. However, there has been a dramatic growth in commuting by car during the postsocialist years. It seems that today public transport is able to offer a reasonable alternative to car-commuting in the suburban satellite towns only, while most of the new residential development takes place in rural areas [9]. 


\section{Conclusion}

Based on the traffic count, the data of the Tax and Customs Board and public databases, the following conclusions can be drawn from the article:

1. The closer a local municipality unit is to Tallinn, the fewer local people are working their own municipality. In other words: the closer to Tallinn a local municipality lies, the higher the percent of its inhabitants working in Tallinn.

2. According to the Road Register and the database of the Tax and Customs Board it can be argued that the everyday commuting zone of Tallinn is approximately 30 kilometres.

3. Suburban people are highly dependent on automobiles because of the poor connections of public transport. Tartu, Narva and Pärnu (186, 211 and $128 \mathrm{~km}$ from Tallinn respectively) have equal or sometimes even better public transport connections than Tallinn has with its neighbouring local municipalities.

4. The mobility demand may be affected by changes in population age composition. In the next 30-40 years the age pyramid would decrease significantly especially in the working age groups who are the main commuters.

To find solutions for transport problems caused by urban sprawl may we apply so-called do-minimum approach? At its extreme this approach assumes that traffic congestion, road accidents, and environmental degradation are inescapable features of modern-day life and, if left to itself, human ingenuity and self-interest will ensure that congestion will become self-regulating before it becomes intolerable. In practice, the do-minimum approach is used as a basis for comparison with 'do-something' proposals [10].

In most large cities today traffic congestion is, in a sense, self-regulating. For example, despite enormous economic change, and with only limited new road construction, the average speeds of traffic in London have not changed dramatically over many decades [11]. However, Tallinn is not London and we have a scope for manoeuvre, which means that our average traffic speed may go up or down depending on the situation in the economy (as we see in Figure 3) or other indicators. This means that we have to carry on with conducting surveys to find out the key factors of mobility demand, compile action plans to improve transportation systems and thereby avoid unnecessary travel.

Increases in trip lengths - unnecessary travel - is a form of inflation where more travel is "spent", while few if any additional needs are satisfied. In that sense, it is little different from economic inflation. In the latter case, we spend more for goods and receive no additional products for our currency. However, travel inflation is, in a sense, worse even than economic inflation since it leads not only to additional travel but also to additional pollution, fuel use, accidents, and deaths. Therefore, it makes logical sense that if we want to decrease excess travel we must attempt to control land use and urban form [2]. 
The authors' long-term objective is to develop a method that would allow making predictions of traffic volumes based on the public databases as well as the demand base modelling.

\section{Acknowledgements}

We wish to thank Mrs Heidi Lillemägi, the chief specialists of Estonian Tax and Customs Board, who was willing to process and issue information necessary to this survey. The authors would also like to convey thanks to Ilomai Küttim for editing the paper.

\section{References}

[1] Grava, S. Urban Transportation Systems: Choices for Communities. McGraw-Hill, New York, pp. 156-157, 2003.

[2] Black, W.R. Sustainable Transportation: Problems and Solutions. The Guildford Press: New York, pp. 105-106, 2010.

[3] Tooming, U. Andres Pajula: lastele kooli määramise määrust Tallinnas veel ei ole [Andres Pajula: There is no regulation for determination the children to school in Tallinn]. http://www.tallinnapostimees.ee/?id=331537.

[4] Statistic Estonia. http://www.stat.ee/

[5] Metsvahi, T. Liiklusvoogude muutumine Tallinna linna ja selle kesklinna piiril 2010. aastal [Traffic volumes at Tallinn town and centre cordon boardes in 2010]. Tallinn University of Technology: Tallinn, 2010.

[6] Maamägi, A. Population prognosis and age distribution in Estonia up to the year 2050. Population Statistics Service: Tallinn 2006.

[7] Leetma, K. Residential suburbanisation in the Tallinn metropolitan area. University of Tartu: Tartu, 2008.

[8] Road Register. http://teeregister.riik.ee/

[9] Leetma, K., Metspalu, P. \& Tammaru, T. Suburbanisation and commuting modes in the Tallinn metropolitan area. The Sustainable City IV: Urban Regeneration and Sustainability, Vol 93, 2006.

[10] O'Flaherty, C.A. Transport Planning and Traffic Engineering, Elsevier Butterworth-Heinemann, Oxford, pp 132-133, 2003.

[11] Transport statistics Great Britain. London: HMSO, 1994. 